\title{
Laju nitrifikasi pada bioremediasi air limbah organik menggunakan Chlorella sp. dan bakteri nitrifikasi-denitrifikasi
}

\section{Nitrification rate in the bioremediation of organic wastewater using Chlorella sp. and nitrifying- denitrifying bacteria}

Arya Ksatria Fernanda Hendrawan ${ }^{\mathrm{a}}$, Norma Afiatia, Arif Rahman ${ }^{\mathrm{a}}$

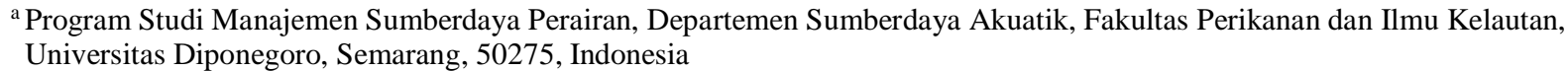

\section{Article Info:}

Received: 09 - 02 - 2021

Accepted: 10 - 06 - 2021

Keywords:

Bioremediation, Chlorella sp., nitrification, nitrifying-

denitrifying bacteria, organic waste

Corresponding Author:

Arya Ksatria Fernanda

Hendrawan

Departemen Sumberdaya

Akuatik, Fakultas Perikanan dan

Ilmu Kelautan, Universitas

Diponegoro;

Tel. +628588236021

Email:

aryaksatria@students.undip.ac.id

\begin{abstract}
Global nitrogen pollution in the aquatic environment has been increased mostly due to the disposal of organic wastewater from human activities. Chronic disposal of nitrogen compounds into the waters caused eutrophication and death of aquatic organisms. The process of reducing nitrogen in wastewater can be carried out economically and efficiently using nitrifying-denitrifying bacteria. Besides that, another environmentally friendly technology that can also be used is bioremediation using microalgae such as Chlorella sp. The synergistic relationship between bacteria and microalgae has a better performance in reducing nitrogen compounds in organic wastewater. This study aims to determine the rate of nitrification, changes in nitrate concentrations, and the effect of differences in treatments and time on changes in nitrate levels in organic wastewater. This study was conducted from July to August 2020 was an experimental laboratory using a randomized block design. Organic wastewater samples were taken from Lake Rawa Pening Central Java. The results showed the highest nitrification rate was performed by treatment $C$ (a combination of probiotics and Chlorella sp.)

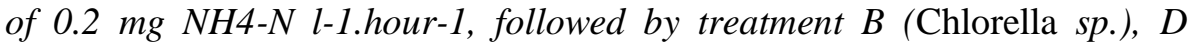

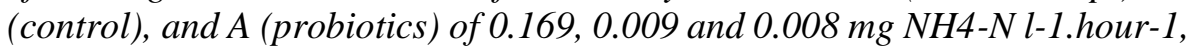
respectively. The highest percentage change in nitrate levels during the study was treatment $C$ (1 874\%), B (1 664\%), D (200\%), and $A(175 \%)$, respectively. The analysis of variance and the DMRT test showed that there were differences between treatments and times of changes in nitrate levels ( $p$ value <0.05), with the highest average change in nitrate levels found in treatment $C$.
\end{abstract}

How to cite (CSE Style $8^{\text {th }}$ Edition):

Hendrawan AKF, Afiati N, Rahman A. 2021. Laju nitrifikasi pada bioremediasi air limbah organik menggunakan Chlorella sp. dan bakteri nitrifikasi-denitrifikasi. JPSL 11(2): 309-323. http://dx.doi.org/10.29244/jpsl.11.2.309-323.

\section{PENDAHULUAN}

Pencemaran nitrogen secara global meningkat sejak akhir abad ke-20 seiring dengan pertumbuhan ekonomi negara berkembang. Tidak hanya itu, di negara-negara maju seperti Eropa Utara, pencemaran nitrogen juga terjadi akibat produksi pangan secara belebihan (Martinez et al., 2019). Nitrogen yang masuk ke perairan menjadi penyebab eutrofikasi yang dapat merusak ekosistem perairan (LIPI, 2015). Di Indonesia, ancaman terhadap lingkungan terjadi simultan di berbagai wilayah tanah air akibat pembuangan air limbah 
nitrogen yang tidak terkendali. Seiring dengan meningkatnya pembangunan di tanah air, tingkat pencemaran nitrogen ke perairan pun menjadi semakin meningkat (Suswanti et al., 2019). Data WWF tahun 2018 menunjukkan bahwa dari 550 sungai yang ada di Indonesia, sebanyak 82 persen berada dalam kondisi rusak. Selain itu, seiring berjalannya waktu terjadi perubahan status trofik perairan di Indonesia akibat pencemar nitrogen, salah satunya terjadi di danau Rawa Pening (Zulfia dan Aisyah, 2013).

Senyawa nitrogen di dalam air dapat berubah-ubah melalui proses nitrifikasi dan denitrifikasi (Prabowo, 2017). Nitrifikasi dan denitrifikasi di dalam siklus nitrogen memiliki peran penting pada produksi primer perairan dan termasuk siklus nutrien yang utama (Paul et al., 2020). Pada proses nitrifikasi, senyawa anorganik amonia dirubah menjadi nitrit, kemudian menjadi nitrat oleh bakteri nitrifikasi, sedangkan dalam proses denitrifikasi senyawa nitrat dirubah menjadi $\mathrm{N}_{2} \mathrm{O}$ (Herlambang dan Marsidi, 2003). Berbeda dengan amonia, nitrat merupakan nutrien paling dominan (Adyasari et al., 2018), yang dapat memengaruhi produktivitas perairan. Oleh karena itu, reaksi nitrifikasi sangat penting bagi keseimbangan nitrogen dan faktor penentu kualitas perairan (Paul et al., 2020).

Dalam waktu yang lama, akumulasi senyawa nitrogen yang terjadi secara terus-menerus tinggi dapat mencemari lingkungan perairan dan menjadi penyebab terjadinya kematian biota air (Rustadi, 2009) dan eutrofikasi, sehingga terjadi blooming fitoplankton dan tumbuhan air lainnya (Lihawa dan Mahmud, 2017). Oleh karena itu, teknologi yang tepat dan ramah lingkungan untuk mengurangi kandungan senyawa nitrogen pada air limbah diperlukan guna mencegah pencemaran. Proses reduksi senyawa nitrogen pada air limbah dapat dilakukan dengan berbagai cara, salah satunya yang tergolong ekonomis dan efisien adalah menggunakan bakteri denitrifikasi (Agustiyani et al., 2007). Adapun, teknologi yang juga dapat digunakan untuk mengurangi kandungan nitrogen pada air limbah adalah bioremediasi, secara umum menggunakan mikroalga seperti Chlorella sp. (Chen dan Wang, 2020).

Mikroalga memiliki kelebihan melalui kemampuannya mengasimilasi senyawa amonia dan nitrat untuk pertumbuhan (Chen dan Wang, 2020) dan untuk memenuhi kebutuhan fotosintesis yang menghasilkan produksi primer (Lomas dan Lipschultz, 2006). Selain itu, mikroalga juga memanfaatkan karbon dioksida yang dihasilkan bakteri melalui respirasi aerob untuk memproduksi oksigen bagi kebutuhan bakteri aerob dalam mengoksidasi senyawa nitrogen dan menguraikan bahan organik (Kwon et al., 2019).

Penelitian oleh Herlambang dan Marsidi (2003) menunjukkan bahwa proses denitrifikasi pada air limbah dapat menghilangkan konsentrasi nitrat sebanyak 100\% dalam 7 hari. Dari penelitian lain oleh Taziki et al. (2015) dan Al-Mamoori et al. (2020), diketahui bahwa pada percobaan bioremediasi limbah cair menggunakan Chlorella sp., efisiensi reduksi konsentrasi nitrat mencapai $88.17 \%$ dan $86 \%$. Adanya hubungan sinergis dari bakteri dan mikroalga berpotensi meningkatkan kinerja reduksi senyawa nitrogen nitrat pada air limbah (Ma et al., 2014). Lebih lanjut, gabungan kultur bakteri dapat meningkatkan efisiensi reduksi senyawa nitrat dalam air (Kwon et al., 2019). Penelitian ini bertujuan untuk mengetahui laju nitrifikasi dan perubahan kadar nitrat, serta pengaruh perbedaan perlakuan dan waktu terhadap perubahan kadar nitrat pada air limbah organik.

\section{METODE}

\section{Hipotesis Penelitian}

1. Hipotesis Variabel Perlakuan

$\mathrm{H}_{0}=$ Tidak terdapat perbedaan antar perlakuan aplikasi probiotik dan mikroalga Chlorella sp. Terhadap perubahan (peningkatan) kadar nitrat.

$\mathrm{H}_{1}=$ Terdapat perbedaan antar perlakuan aplikasi probiotik dan mikroalga Chlorella sp. terhadap perubahan (peningkatan) kadar nitrat.

2. Hipotesis Variabel Waktu

$\mathrm{H}_{0}=$ Tidak terdapat perbedaan antar perlakuan aplikasi probiotik dan mikroalga Chlorella sp. terhadap perubahan (peningkatan) kadar nitrat. 
$\mathrm{H}_{1}=$ Terdapat perbedaan antar perlakuan aplikasi probiotik dan mikroalga Chlorella sp. terhadap perubahan (peningkatan) kadar nitrat.

\section{Lokasi dan Waktu Penelitian}

Penelitian dilakukan selama 18 hari pada bulan Juli hingga Agustus 2020 di Laboratorium Hidrobiologi dan Laboratorium Pengelolaan Sumberdaya Ikan dan Lingkungan (PSDIL), Departemen Sumberdaya Akuatik, serta Laboratorium Biologi, FPIK, Universitas Diponegoro.

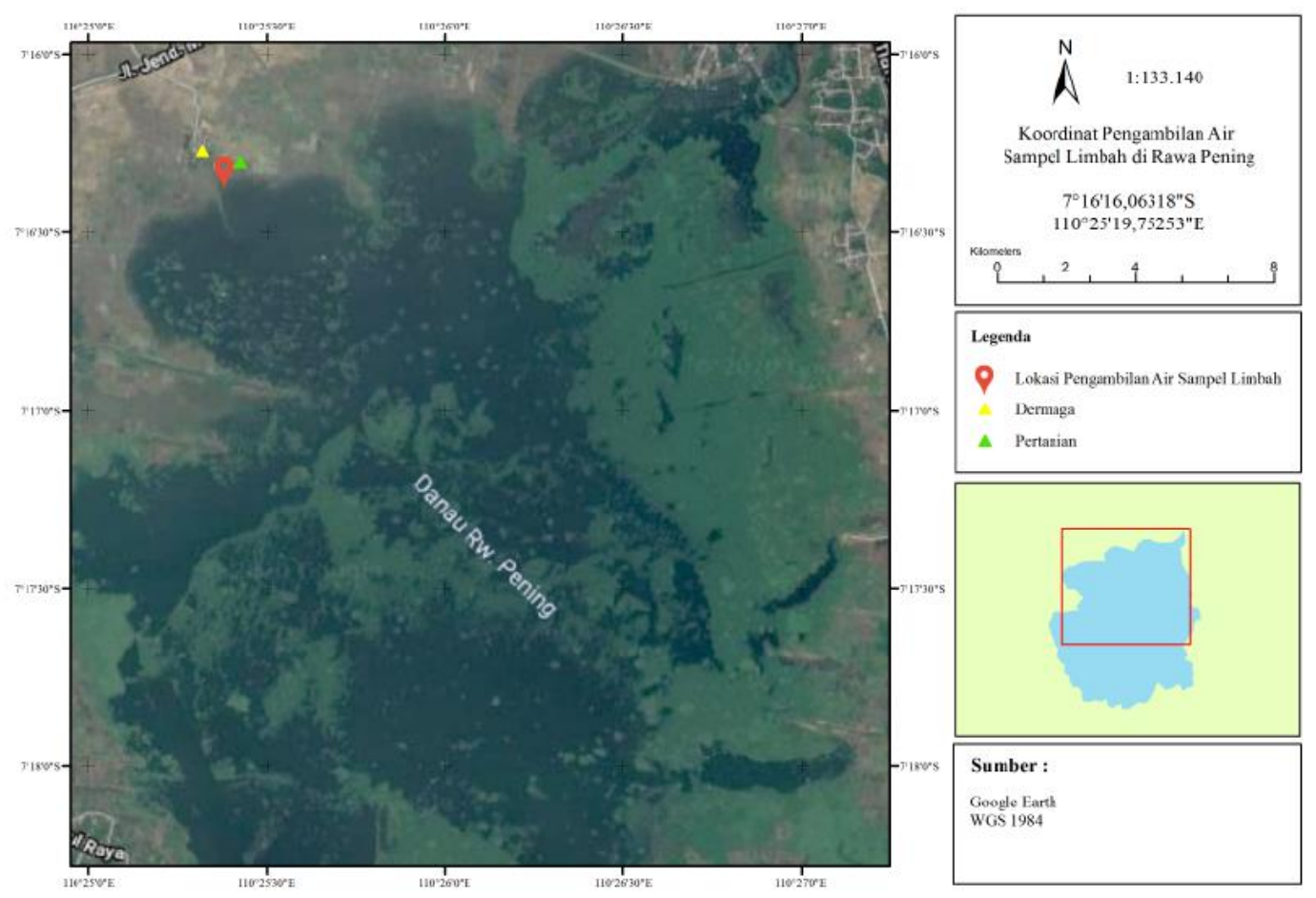

Gambar 1 Peta lokasi pengambilan sampel air Danau Rawa Pening

\section{Alat dan Bahan}

Alat yang digunakan diantaranya adalah Spektrofotometer Hach 2000 untuk pengukuran kadar nitrat. Mikroskop, aerator, akuarium 12 liter, lampu LED grow light, botol sampel $600 \mathrm{ml}$, slide glass dan SedgewickRafter Counting Cell untuk pengukuran kelimpahan mikroalga Chlorella sp. Cawan Petri, hand counter, tabung reaksi, inkubator, Erlenmeyer $1000 \mathrm{ml}$, mikropipet dan hotplate magnetic stirer untuk pengukuran Angka Lempeng Total (ALT). Gelas Beaker $100 \mathrm{ml}$, gelas ukur $100 \mathrm{ml}$, pipet ukur $25 \mathrm{ml}$, kuvet dan serta thermometer, DO meter dan $\mathrm{pH}$ meter untuk mengukur variabel kualitas air.

Bahan yang digunakan diantaranya yaitu air limbah 48 liter, probiotik starter bakteri nitrifikasidenitrifikasi yang diperoleh dari toko online, yang terdiri dari konsorsium bakteri Bacillus pumilusmegaterium, Thiobacilus denitrificans, Nitrosomonas sp. dan Nitrobacter sp., kultur mikroalga Chlorella pyrenoidosa, pupuk Walne, akuades steril dan Plate Count Agar (PCA). Adapun bahan yang digunakan untuk analisis laboratorium diantaranya reagen Nitrate ver 5 Nitrate untuk pengukuran kadar nitrat.

\section{Pengambilan Sampel Air Limbah}

Pengambilan sampel air limbah dilakukan dengan metode grab sample pada lokasi tertentu berdasarkan SNI 6989.59:2008. Sampel air limbah diambil sebanyak 48 liter untuk kebutuhan 6 liter air per akuarium dengan mengisi air menggunakan gayung dan ember, kemudian dimasukkan ke dalam wadah sampel (jerigen), ditutup dengan rapat dan dibawa ke laboratorium. Lokasi pengambilan sampel air limbah pada satu titik, 
terletak di Danau Rawa Pening, Ambarawa, Jawa Tengah pada koordinat 7 $16^{\prime} 16.06318$ "S 110 25'19.75253"E antara area pertanian dan dermaga berdasarkan peta lokasi pengambilan air sampel pada Gambar 1. Hal tersebut mengacu pada penelitian Zulfia dan Aisyah (2013), dimana kadar nitrogen yang diperoleh cukup tinggi terdapat pada wilayah perairan dekat dengan dermaga.

\section{Penelitian Pendahuluan}

Penelitian pendahuluan dimaksudkan untuk mempersiapkan kultur mikroalga Chlorella sp. dan mengetahui laju pertumbuhannya pada sampel segar limbah cair organik. Tahap awal dimulai dengan kultur Chlorella sp. dari $250 \mathrm{~mL}$ bibit kultur Chlorella sp. yang dimasukkan ke dalam Erlenmeyer $1000 \mathrm{ml}$, diencerkan dengan akuades sebanyak $750 \mathrm{ml}$ dan ditambah dengan pupuk Walne sebanyak $2.5 \mathrm{~mL}$. Pupuk Walne mengandung larutan nutrien, larutan trace metal, vitamin B12, thiamin dan biotin yang berfungsi memberikan nutrisi untuk mendukung pertumbuhan Chlorella sp. Setelah itu, bibit kultur Chlorella sp. sebanyak $250 \mathrm{ml}$ dimasukkan ke dalam akuarium berisi sampel segar limbah cair organik 6 liter diberikan aerator sebagai sumber oksigen dan pencahayaan menggunakan lampu LED grow light 3 watt sebagai sumber cahaya untuk fotosintesis karena apabila wadah uji diletakkan di dalam ruangan, dapat ditambah dengan lampu LED sebagai susbstitusi cahaya matahari yang diperlukan mikroalga selama proses fotosintesis (Rusdiani $e t$ al., 2016).

Pengukuran kelimpahan awal sel mikroalga Chlorella sp. dengan selang waktu 5, 10, 30, 60 menit, dilanjutkan menjadi 2, 4, 6, 8, 12, 16 dan 24 jam pada 24 jam pertama. Pengamatan hari berikutnya dilakukan dengan selang waktu 24 jam dimulai pada pada pukul 08.00 WIB setiap harinya, hingga laju pertumbuhan mikroalga Chlorella sp. mencapai fase penurunan yaitu hari ke-9 (Prayitno, 2015). Ketika kultur Chlorella sp. mencapai fase pertumbuhan puncak (hari ke-7) (Prayitno, 2015), bibit kultur Chlorella sp. tersebut digunakan sebagai bahan untuk rancangan percobaan, sambil tetap melanjutkan pengamatan hingga hari ke 9.

\section{Rancangan Percobaan}

Penelitian ini bersifat eksperimental laboratoris menggunakan Rancangan Acak Kelompok dengan pengelompokan berdasarkan dua faktor dan dua ulangan. Adapun, faktor-faktor tersebut adalah faktor perlakuan (4 taraf) yaitu perlakuan A (probiotik), B (mikroalga Chlorella sp.), C (kombinasi mikroalga Chlorella sp. dan probiotik) dan D (kontrol), sedangkan faktor waktu (4 taraf) meliputi hari ke-0, ke-3, ke-6 dan hari ke-9 (Gambar 2). Rancangan percobaan pada penelitian ini dilakukan untuk mengetahui pengaruh pemberian perlakuan terhadap perubahan kadar nitrat pada waktu pengamatan yang berbeda. Percobaan ini dilakukan selama 9 hari untuk mengetahui variasi kadar nitrat yang terkandung pada setiap wadah uji. Skema rancangan percobaan disimulasikan dalam wadah uji berupa akuarium berisi 6 liter sampel air limbah organik yang diberi perlakuan berbeda dengan dua ulangan. Wadah disusun seperti Gambar 2.

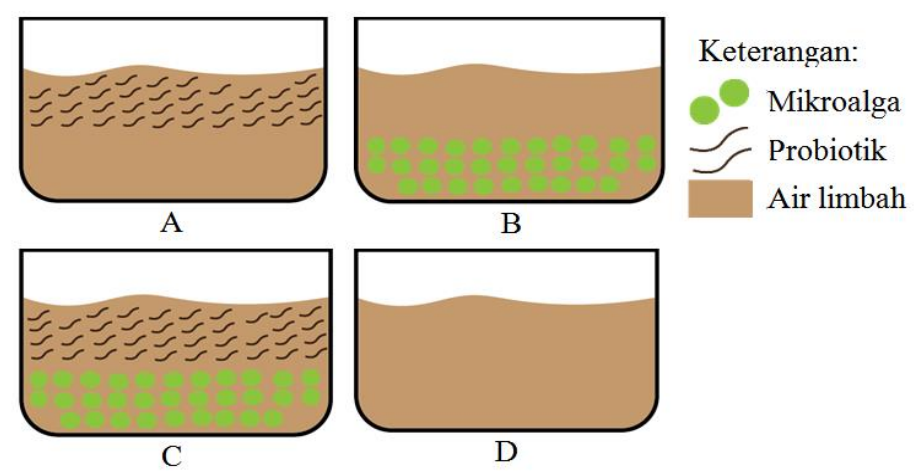

Gambar 2 Skema rancangan percobaan tiga perlakuan dengan dua ulangan dan kontrol: A. Perlakuan dengan probiotik (bakteri nitrifikasi-denitrifikasi), B. Perlakuan dengan mikroalga Chlorella sp., C. Kombinasi mikroalga Chlorella sp. dan probiotik, D. Kontrol tanpa perlakuan 
Setiap wadah uji perlakuan probiotik diberi probiotik sebanyak $7.2 \times 10^{-3}$ gr (Suprianto et al., 2019), sedangkan penambahan mikroalga Chlorella sp. sebanyak $100 \mathrm{ml}$ dari bibit kultur Chlorella sp. yang telah diketahui kelimpahan selnya, diukur sebelum percobaan pendahuluan yaitu sebesar $183.4 \times 10^{3} \mathrm{sel} / \mathrm{L}$. Wadah D berisi air limbah tanpa penambahan probiotik maupun mikroalga Chlorella sp atau sebagai wadah kontrol.

\section{Pengukuran Variabel Kualitas Air}

Pengukuran kualitas air dilakukan pada sampel air dari wadah uji, meliputi variabel kimia dan fisika. Waktu pengukuran variabel kimia dan fisika kualitas air yang meliputi $\mathrm{pH}, \mathrm{DO}$, kadar nitrat, temperatur air dan udara adalah setiap 3 hari selama 9 hari yaitu pada waktu (jam) ke-0, ke-72, ke-144 dan ke-216 (Cytryn et al., 2012), yang dilakukan selama rancangan percobaan.

Pengukuran variabel oksigen terlarut (Dissolved Oxygen, DO) dilakukan menggunakan DO-meter dengan cara memasukkan reference electrode ke dalam air (Carritt dan Kanwisher, 1959). Pengukuran temperatur air dan udara dilakukan menggunakan thermometer dengan memasukkan sensor temperatur ke dalam sampel air (EPA, 1974). Pengukuran $\mathrm{pH}$ dilakukan menggunakan $\mathrm{pH}$ meter dengan cara memasukkan sensor $\mathrm{pH}$ ke dalam air (Karangan et al., 2019). Kemudian pengukuran kadar nitrat dilakukan dengan metode Hach Programme menurut Arizuna et al. (2014) dalam Ikhsan et al. (2020).

\section{Kelimpahan Chlorella sp.}

Pengamatan kelimpahan mikroalga Chlorella sp. dilakukan menggunakan mikroskop pada pembesaran lensa objektif 10x. Sebelum itu, perlu dilakukan sterilisasi alat yang akan digunakan untuk menghindari kontaminasi biologi seperti kontaminasi Protozoa yang dapat diminimalisir melalui proses sterilisasi peralatan yang akan digunakan sesuai Standard Operational Procedure (SOP). Air sampel diambil sebanyak $1 \mathrm{ml}$ dan ditambahkan ke dalam Sedgewick-Rafter Counting Cell, kemudian ditutup dengan slide glass. Apabila kelimpahan sel terlalu tinggi, dilakukan pengenceran dengan akuades. Kelimpahan mikroalga dihitung menggunakan rumus APHA (1989), yaitu:

Dimana:

$$
\mathrm{N}=\mathrm{n} \times \frac{\mathrm{V}_{\mathrm{c}}}{\mathrm{V}_{\mathrm{src}}} \times \frac{\mathrm{A}_{\mathrm{src}}}{\mathrm{A}_{\mathrm{a}}} \times \frac{1}{\mathrm{~V}_{\mathrm{k}}}
$$

$\mathrm{N}$ = Kelimpahan mikroalga (sel/L)

$\mathrm{n} \quad=$ Jumlah mikroalga yang diamati

$\mathrm{V}_{\mathrm{c}}=$ Volume air yang diambil $(1 \mathrm{ml})$

$\mathrm{V}_{\text {src }}=$ Volume air dalam Sedgewick-Rafter Counting Cell $(1 \mathrm{ml})$

$\mathrm{A}_{\mathrm{a}}=$ Luas total petak Sedgewick-Rafter Counting Cell yang diamati $\left(30 \mathrm{~mm}^{2}\right)$

$\mathrm{A}_{\mathrm{src}}=$ Luas area Sedgewick-Rafter Counting Cell $\left(1000 \mathrm{~mm}^{2}\right)$

$\mathrm{V}_{\mathrm{k}}=$ Volume kultur (6 liter)

\section{Perhitungan Kelimpahan Total Bakteri}

Pengukuran kelimpahan total bakteri dilakukan pada awal dan akhir rancangan percobaan. Kelimpahan total bakteri dengan media PCA atau Plate Count Agar dihitung menggunakan metode Angka Lempeng Total (ALT) sesuai SNI 01-2332.3-2006 dengan pengenceran sampel bakteri secara bertingkat dan penanaman bakteri menggunakan teknik spread plate. 


\section{Metode Analisis Data}

\section{Analisis Perubahan Kadar Nitrat}

Persentase perubahan kadar nitrat mengacu pada perhitungan persen perubahan kualitas air (Arifin, 2000), yang dirumuskan sebagai berikut:

$$
E=\frac{B-A}{A} \times 100 \%
$$

\section{Keterangan:}

$\mathrm{E}=$ Persentase perubahan kadar nitrat selama percobaan

$\mathrm{A}=$ Kadar nitrat di awal percobaan $(\mathrm{mg} / \mathrm{l})$

$\mathrm{B}=$ Kadar nitrat di akhir percobaan $(\mathrm{mg} / \mathrm{l})$

\section{Laju Nitrifikasi (Nitrification Rate)}

Laju nitrifikasi dengan satuan mg NH4-N 1-1.jam-1, indikatornya adalah peningkatan atau penurunan kadar nitrat, menurut Gilhawley (2008) diestimasikan dalam persamaan sebagai berikut:

$$
\text { Laju nitrifikasi }\left(\mathrm{NH}_{4}-\mathrm{N}^{-1} \cdot \mathrm{jam}^{-1}\right)=\left(\frac{\mathrm{C}_{\mathrm{x}, \mathrm{NO}_{3}}-\mathrm{C}_{0, \mathrm{NO}_{3}}}{\mathrm{t}_{\mathrm{x}}}\right) / 24
$$

Keterangan:

$\mathrm{C}_{\mathrm{x}, \mathrm{NO}_{3}}=$ Kadar nitrat di waktu ke-x (di akhir percobaan) (mg/l)

$\mathrm{C}_{0, \mathrm{NO}_{3}}=$ Kadar nitrat di waktu ke-0 (di awal percobaan) (mg/l)

tx $\quad=$ Waktu ke-x (jam)

\section{Analisis Sidik Ragam Univariate dan Uji Duncan Multiple Range Test}

Analisis data pada rancangan acak kelompok ini menggunakan analisis sidik ragam univariate, untuk menguji hipotesis dengan dua variabel atau lebih. Analisis sidik ragam pada penelitian ini menggunakan Aplikasi SPSS 25. Model matematik Rancangan Acak Kelompok ini ditunjukkan dalam formula berikut:

Keterangan:

$$
\mathrm{Y}_{\mathrm{ij}}=\mu+\alpha_{\mathrm{i}}+\beta_{\mathrm{j}}+\varepsilon_{\mathrm{i}}
$$

Yij = Pengaruh pengamatan pada perlakuan ke-i dan waktu ke- $\mathrm{j}$

$\mu \quad=$ Rataan umum

$\alpha \mathrm{i}=$ Pengaruh perlakuan ke-i

$\beta \mathrm{j}=$ Waktu ke-j

$\varepsilon \mathrm{ij}=$ Pengaruh acak dari waktu dengan perlakuan $(0, \sigma 2)$

Uji linearitas atau uji pengaruh dilakukan untuk mengetahui hubungan linear antara variabel dependen dengan setiap variabel independen yang diuji. Uji pengaruh diperoleh dengan membandingkan nilai $p$-value (signifikansi) dengan $\alpha$ (taraf signifikansi). Jika $p$-value $(\alpha)<0.05$, maka dikatakan $\mathrm{H}_{0}$ ditolak (Djazari et al., 2013). Pada kondisi demikian, aplikasi probiotik (bakteri nitrifikasi-denitrifikasi) dan kultur mikroalga Chlorella sp. dapat berpengaruh terhadap kenaikan/penurunan kadar nitrat. Menurut Mattjik dan Sumertajaya (2000), jika kesimpulan uji pengaruh yang didapatkan menolak $\mathrm{H}_{0}$, yang dalam hal ini adalah aplikasi probiotik dan kultur mikroalga memberikan pengaruh yaitu berbeda nyata terhadap perubahan kadar nitrat, maka dilakukan uji lanjut, yaitu uji perbandingan berganda Duncan atau Duncan Multiple Range Test (DMRT) untuk menentukan perlakuan mana yang menyebabkan terjadinya penolakan terhadap $\mathrm{H}_{0}$. Menurut Persulessy et al. (2016), uji Duncan Multiple Range Test (DMRT) digunakan untuk menguji beda nilai rata-rata dari urutan nilai rata-rata tiap perlakuan dari terbesar sampai yang terkecil atau sebaliknya. 


\section{HASIL DAN PEMBAHASAN}

\section{Kelimpahan Bakteri dan Kondisi Kualitas Air Selama Percobaan}

Hasil pengukuran kelimpahan bakteri, $\mathrm{pH}$, dissolved oxygen (DO) dan temperatur ditunjukkan pada Tabel 1. Kelimpahan bakteri pada setiap perlakuan menunjukkan bahwa kelimpahan bakteri pada akhir pengamatan lebih tinggi daripada awal pengamatan yang berarti terjadi peningkatan kelimpahan bakteri. Pada perlakuan probiotik (perlakuan A), kelimpahan bakteri meningkat dari $2.6 \times 10^{4} \mathrm{cfu} / \mathrm{ml}$ menjadi $35.3 \times 10^{4} \mathrm{cfu} / \mathrm{ml}$. Pada perlakuan kombinasi (perlakuan C), kelimpahan total bakteri meningkat dari $3.05 \times 10^{4} \mathrm{cfu} / \mathrm{ml}$ menjadi $23.5 \mathrm{x}$ $10^{4} \mathrm{cfu} / \mathrm{ml}$. Peningkatan kelimpahan total bakteri hingga akhir pengamatan dipengaruhi oleh kandungan oksigen terlarut (DO) yang tinggi, sehingga membantu kinerja bakteri dalam proses nitrifikasi dan denitrifikasi (Cui et al., 2019). Sebaliknya pada kondisi oksigen terlarut (DO) yang rendah, pertumbuhan bakteri akan menjadi lambat dan dapat menghambat proses nitrifikasi dan denitrifikasi (Chen et al., 2020).

Tabel 1 Kondisi kualitas air pada perlakuan A (probiotik), B (Chlorella sp.), C (kombinasi probiotik dan Chlorella sp.), D (kontrol tanpa perlakuan)

\begin{tabular}{|c|c|c|c|c|c|c|}
\hline \multirow{2}{*}{ Variabel } & \multirow{2}{*}{ Perlakuan } & \multicolumn{4}{|c|}{ Hari ke- } & \multirow{2}{*}{ Rata-rata } \\
\hline & & 0 & 3 & 6 & 9 & \\
\hline Kelimpahan & $\bar{A}$ & $2.60 \times 10^{4}$ & - & - & $35.3 \times 10^{4}$ & - \\
\hline Bakteri (cfu/ml) & $\mathrm{C}$ & $3.05 \times 10^{4}$ & - & - & $23.5 \times 10^{4}$ & - \\
\hline \multirow{4}{*}{$\mathrm{pH}$} & A & 8.11 & 8.05 & 8.13 & 8.18 & $8.12 \pm 0.05$ \\
\hline & B & 8.00 & 8.08 & 8.02 & 6.64 & $7.68 \pm 0.14$ \\
\hline & $\mathrm{C}$ & 7.87 & 8.05 & 7.17 & 6.67 & $7.44 \pm 0.6$ \\
\hline & $\mathrm{D}$ & 7.78 & 8.12 & 8.13 & 8.21 & $8.06 \pm 0.02$ \\
\hline \multirow{4}{*}{$\begin{array}{l}\text { DO } \\
(\mathrm{mg} / \mathrm{l})\end{array}$} & $\mathrm{A}$ & 11.30 & 10.55 & 9.90 & 9.75 & $10.38 \pm 0.07$ \\
\hline & B & 11.05 & 10.45 & 10.00 & 9.90 & $10.35 \pm 0.14$ \\
\hline & $\mathrm{C}$ & 10.9 & 10.55 & 10.20 & 10.05 & $10.43 \pm 0.07$ \\
\hline & $\mathrm{D}$ & 10.95 & 10.75 & 10.30 & 10.05 & $10.51 \pm 0.05$ \\
\hline \multirow{4}{*}{$\begin{array}{l}\text { Temperatur } \\
\text { Air } \\
\left({ }^{\circ} \mathrm{C}\right)\end{array}$} & $\mathrm{A}$ & 25.05 & 25.86 & 25.75 & 26.20 & $25.71 \pm 0.13$ \\
\hline & B & 25.30 & 25.75 & 25.60 & 26.10 & $25.69 \pm 0.09$ \\
\hline & $\mathrm{C}$ & 25.50 & 25.55 & 25.65 & 26.00 & $25.68 \pm 0.04$ \\
\hline & $\mathrm{D}$ & 25.85 & 25.65 & 25.70 & 26.10 & $25.83 \pm 0.07$ \\
\hline \multicolumn{2}{|c|}{ Temperatur Udara $\left({ }^{\circ} \mathrm{C}\right)$} & 24 & 24 & 24 & 24 & 24 \\
\hline
\end{tabular}

Variabel pH pada perlakuan C (kombinasi) dan B (Chlorella sp.) mengalami penurunan pH hingga akhir pengamatan dengan rata-rata $\mathrm{pH}$ yang paling rendah yaitu $7.44 \pm 0.6$ dan $7.68 \pm 0.14$, sedangkan perlakuan $\mathrm{A}$ (probiotik) dan $\mathrm{D}$ (kontrol) relatif mengalami peningkatan dengan rata-rata $8.12 \pm 0.05$ dan $8.06 \pm 0.02$. Sebagian besar pH berada pada kondisi optimal berkisar antara 7.9-8.1 (Grunditz dan Dalhammar, 2001). Kandungan oksigen terlarut (DO) setiap perlakuan mengalami penurunan dengan rata-rata tertinggi adalah perlakuan D (kontrol) yaitu $10.51 \pm 0.05 \mathrm{mg} / \mathrm{l}$, diikuti dengan perlakuan C (kombinasi) yaitu $10.43 \pm 0.07 \mathrm{mg} / \mathrm{l}$, perlakuan A (probiotik) yaitu $10.38 \pm 0.07 \mathrm{mg} / \mathrm{l}$ dan perlakuan B (Chlorella sp.) yaitu $10.35 \pm 0.14 \mathrm{mg} / \mathrm{l}$. Variabel temperatur memiliki angka yang relatif homogen dan mengalami peningkatan hingga akhir pengamatan pada setiap perlakuan yaitu berkisar antara $25-26{ }^{\circ} \mathrm{C}$. Kebutuhan oksigen terlarut (DO) dipenuhi dengan adanya aerasi secara konstan dan temperatur yang dicapai optimal pada $25 \pm 1^{\circ} \mathrm{C}$ (Feng et al., 2020). 


\section{Kelimpahan dan Laju Pertumbuhan Mikroalga Chlorella sp.}

Kelimpahan Chlorella sp. pada percobaan pendahuluan, memiliki pola pertumbuhan yang meningkat hingga mencapai puncak pada hari ke-6 dengan kelimpahan Chlorella sp. tertinggi sebesar $113 \times 10^{3} \mathrm{sel} / \mathrm{L}$. Setelah itu, kelimpahan Chlorella sp. mengalami penurunan hingga hari ke-9 (hari terakhir) dengan kelimpahan terendah sebesar $8.6 \times 10^{3} \mathrm{sel} / \mathrm{L}$ (Gambar 3). Pada pengamatan di hari pertama (hari ke 0), kelimpahan Chlorella sp. meningkat secara drastis mencapai $43 \times 10^{3} \mathrm{sel} / \mathrm{L}$ hingga jam ke 8 , pada waktu memasuki malam hari. Peningkatan kelimpahan Chlorella sp. secara drastis disebabkan karena kandungan nutrien yang berasal dari air limbah dan adanya penambahan pupuk Walne. Menurut Sutomo (2005) dalam Boroh et al. (2019), pada awal pertumbuhan Chlorella sp. memiliki laju pertumbuhan relatif tinggi, menandakan bahwa Chlorella sp. cepat memiliki daya adaptasi lingkungan yang baru sehingga dapat tumbuh dengan cepat. Pada pengamatan berikutnya, kelimpahan Chlorella sp. mengalami penurunan sebesar 13\% hingga $38 \times 10^{3} \mathrm{sel} / \mathrm{L}$, yang menunjukkan sebagian kecil Chlorella sp. tidak dapat bertahan terhadap lingkungan yang baru sehingga Chlorella sp. mengalami pertumbuhan yang lambat (Boroh et al., 2019).

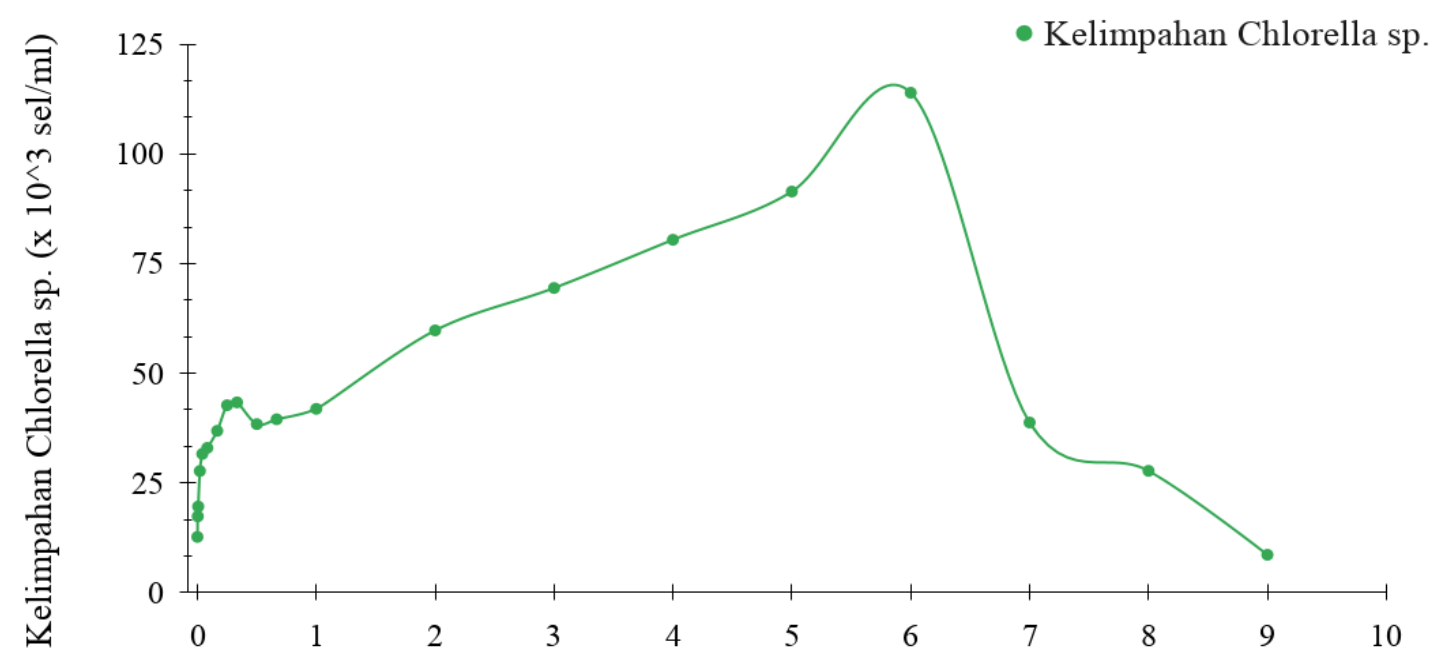

Hari ke-

Gambar 3 Laju pertumbuhan Chlorella sp. pada percobaan pendahuluan

Chlorella sp. mengalami pertumbuhan secara eksponensial mulai hari ke-1 hingga mencapai puncak pada hari ke-6 dengan kelimpahan sebesar $113 \times 10^{3}$ sel/L. Hal ini disebabkan ketersediaan unsur hara nitrogen membuat pembelahan sel masih terus berlangsung hingga masa puncak eksponensial, dan menurun secara signifikan pada hari ke-7 menjadi $38 \times 10^{3} \mathrm{sel} / \mathrm{L}$. Menurut Fogg (1965) dalam Chilmawati dan Suminto (2008), penurunan kelimpahan Chlorella sp. setelah masa puncak disebabkan karena berkurangnya nutrien diikuti dengan peningkatan jumlah populasi Chlorella sp., sehingga Chlorella sp. tidak mampu dalam mempertahankan kelimpahan selnya dan terjadi penurunan secara drastis. Selain itu, pada pengamatan ditemukan adanya organisme lain seperti zooplankton yang merupakan predator bagi Chlorella sp. juga merupakan faktor yang memengaruhi penurunan kelimpahan Chlorella sp. Adanya kompetisi, sifat fisik lingkungan (daya dukung), predasi dan sifat genetik menjadi faktor yang memengaruhi kelimpahan Chlorella sp. yang dalam waktu berbeda akan mengalami penurunan populasi akibat faktor tersebut (Boroh et al., 2019)

Kelimpahan Chlorella sp. pada rancangan percobaan yang dilakukan, menunjukkan bahwa pada setiap perlakuan yang dilakukan pengukuran kelimpahan Chlorella sp. yaitu perlakuan B (mikroalga Chlorella sp.) dan perlakuan $\mathrm{C}$ (kombinasi mikroalga dengan probiotik), juga memiliki pola pertumbuhan yang sama seperti pada percobaan pendahuluan yaitu meningkat dari waktu ke waktu pengamatan hingga mencapai hari puncak 
(hari ke-6), kemudian menurun hingga akhir pengamatan (hari ke-9) (Gambar 4). Pada perlakuan C, kelimpahan Chlorella sp. mencapai puncaknya pada $114 \times 10^{3}$ sel/L, sedangkan pada perlakuan B mencapai puncak pada $109 \times 10^{3} \mathrm{sel} / \mathrm{L}$, sedikit lebih rendah dari perlakuan C. Kelimpahan Chlorella sp. pada perlakuan $\mathrm{C}$ dan B hingga hari puncak, masing-masing menunjukkan persentase kenaikan sebesar $82.6 \%$ dan $81.6 \%$. Kelimpahan terendah terjadi pada hari ke-9, yaitu perlakuan B sebesar $4 \times 10^{3}$ sel/L, sedangkan perlakuan C sebesar 4.4 x 103 $\mathrm{sel} / \mathrm{L}$ (Gambar 4). Dari waktu ke waktu pengamatan, kelimpahan Chlorella sp. pada perlakuan $\mathrm{C}$ relatif lebih tinggi daripada perlakuan B. Hal tersebut menandakan bahwa populasi Chlorella sp. pada perlakuan $\mathrm{C}$ lebih tinggi dibandingkan perlakuan B. Tingginya kelimpahan Chlorella sp. didukung oleh adanya faktor kualitas air terutama temperatur, yang menjadi faktor pembatas untuk organisme air (Cech, 2005 dalam Djoharam et al., 2018). Berdasarkan hasil pengamatan temperatur air, menunjukkan bahwa temperatur air memiliki angka yang optimal untuk pertumbuhan mikroalga Chlorella sp. berkisar $25 \pm 1^{\circ} \mathrm{C}$ (Feng et al., 2020).

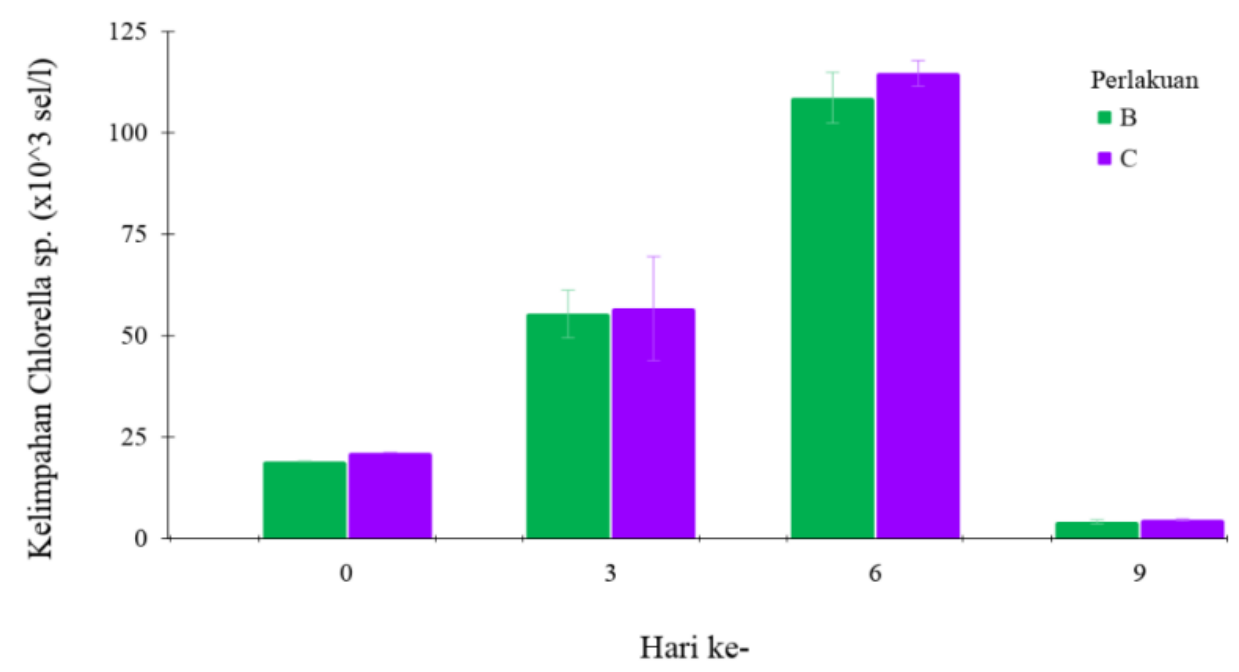

Gambar 4 Rancangan percobaan kelimpahan Chlorella sp. pada perlakuan B (Chlorella sp.) dan C (kombinasi Chlorella sp. dan probiotik)

\section{Perubahan Kadar Nitrat}

Hasil pengukuran variabel nitrat menunjukkan bahwa kadar nitrat berbeda-beda antar perlakuan. Pada perlakuan penambahan probiotik (A) dan perlakuan kontrol (D), variasi nitrat dari hari 0 hingga hari ke 9 memiliki pola yang sama yaitu mengalami penurunan kadar nitrat pada hari ke-3 (Gambar 5). Berbeda dengan perlakuan penambahan mikroalga (perlakuan B) dan kombinasi probiotik dan mikroalga (perlakuan C) yang memperlihatkan pola perubahan yang serupa dengan kenaikan kadar nitrat setiap harinya. Pada perlakuan A dan D, kenaikan kadar nitrat relatif lebih rendah dibandingkan perlakuan B dan C. Hasil perhitungan perubahan kadar nitrat (persamaan 2) menunjukkan bahwa persentase kenaikan kadar nitrat tertinggi adalah perlakuan C (probiotik dan Chlorella sp.) sebesar 1 874\%, diikuti perlakuan B dengan $1664 \%$, perlakuan D sebesar 200\% dan terendah adalah perlakuan A sebesar 175\%.

Kadar nitrat yang meningkat secara signifikan, sangat dipengaruhi oleh faktor lain yang salah satunya adalah pH. Dalam penelitian ini, pada saat angka $\mathrm{pH}$ menurun diikuti oleh peningkatan kadar nitrat seperti pada perlakuan B (mikroalga Chlorella sp.) dan C (kombinasi probiotik dan mikroalga). Peningkatan senyawa nitrat diduga diakibatkan kenaikan senyawa amonium yang dipengaruhi oleh fluktuasi $\mathrm{pH}$. Senyawa amonium dianggap sebagai sumber nitrogen yang hemat energi untuk mikroalga karena dalam penyerapannya membutuhkan lebih sedikit energi dibandingkan nitrat $\left(\mathrm{NO}_{3}\right)$ (Minhas et al., 2016). Fluktuasi $\mathrm{pH}$ yang terjadi akan memengaruhi kesetimbangan amonia $\left(\mathrm{NH}_{3}\right)$ dan ion amonium $\left(\mathrm{NH}_{4}{ }^{+}\right)$di air. Semakin tinggi $\mathrm{pH}$ dan temperatur air akan memungkinkan terbentuknya amonia $\left(\mathrm{NH}_{3}\right)$ yang bersifat toksik, begitu juga sebaliknya. 


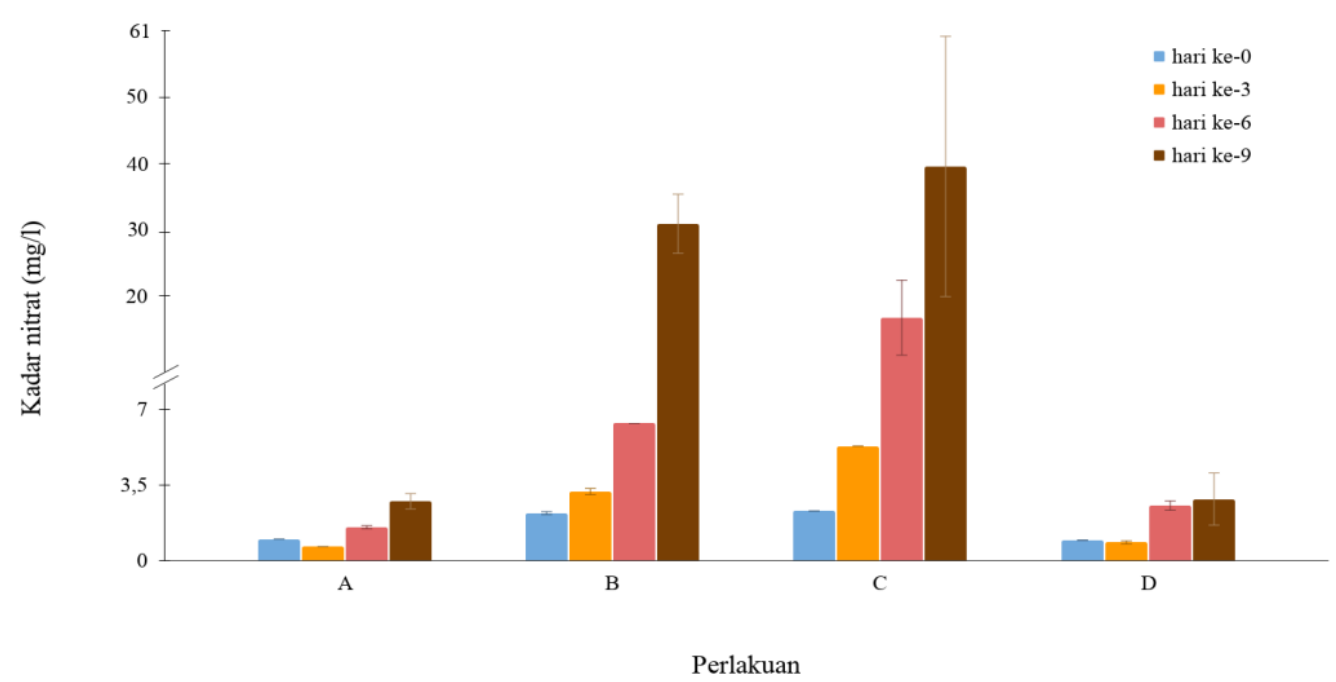

Gambar 5 Persentase perubahan kadar nitrat pada perlakuan A (probiotik), B (Chlorella sp.), C (kombinasi Chlorella sp. dan probiotik), D (kontrol tanpa perlakuan)

Pada perlakuan penambahan probiotik (A) dan kontrol (D), angka pH cenderung meningkat dan berada pada kondisi optimal pH antara 7.9-8.1 (Grunditz dan Dalhammar, 2001). Hal tersebut menandakan bahwa kadar amonia (senyawa amonium) pada perlakuan tersebut meningkat seiring dengan peningkatan $\mathrm{pH}$. Apabila terdapat nitrat dan amonia secara bersamaan, maka nitrat tidak akan diabsorpsi sampai semua amonia habis terserap (Nurhayati et al., 2014). Sementara itu pada perlakuan C (kombinasi), kondisi pH setelah pengamatan hari ke 6, cenderung menurun di bawah kondisi optimal bagi bakteri nitrifikasi dan denitrifikasi $(\mathrm{pH}<7.9)$, sehingga pertumbuhan bakteri melambat, karena pada $\mathrm{pH}$ rendah laju nitrifikasi terjadi secara lambat dan pertumbuhan bakteri menjadi lebih rendah.

Peningkatan senyawa nitrat juga diduga disebabkan karena pada saat fase lag atau fase adaptasi Chlorella sp. terhadap lingkungan yang baru, sebagian Chlorella sp. tidak dapat beradaptasi terhadap air limbah, sehingga sebagian mati dan membentuk nitrogen organik yang menjadi senyawa amonium, kemudian diurai menjadi nitrat oleh bakteri nitrifikasi. Senyawa amonium yang tinggi terbentuk karena proses ionisasi amonia pada $\mathrm{pH}<7$, dan menjadi sumber energi yang lebih disukai oleh Chlorella sp. meskipun senyawa amonia dalam bentuk ini bersifat racun bagi mikroalga (Arifin, 2012). Peningkatan kadar nitrat secara drastis juga sangat dipengaruhi oleh kelimpahan bakteri. Hal ini ditunjukkan pada setiap perlakuan dengan pengukuran kelimpahan total bakteri yaitu perlakuan A (probiotik) dan C (kombinasi probiotik dan mikroalga), memiliki hasil kelimpahan bakteri yang meningkat hingga akhir pengamatan (Tabel 1). Berbeda dengan perlakuan C, perlakuan A (probiotik) memiliki laju nitrifikasi yang paling rendah. Hal tersebut diduga disebabkan karena adanya pengaruh kinerja bakteri denitrifikasi dalam mengurai nitrat menjadi $\mathrm{N}_{2} \mathrm{O}$ dan nitrogen bebas, sehingga kadar nitrat menjadi berkurang yang memengaruhi angka laju nitrifikasi. Sementara itu, pada perlakuan kontrol (D) laju nitrifikasi meningkat disebabkan karena adanya bakteri nitrifikasi yang berasal dari air limbah itu sendiri dan dipengaruhi oleh adanya aerasi.

Menurut Djokosetiyanto et al. (2006), suplai oksigen dari proses aerasi dapat memengaruhi proses nitrifikasi, sehingga jumlah oksigen mencukupi untuk kebutuhan proses merubah senyawa amonia menjadi nitrit dan kemudian nitrat. Organisme dalam air yaitu bakteri heterotrof dan bakteri nitrifikasi-denitrifikasi sangat membutuhkan oksigen untuk mengoksidasi senyawa amonia menjadi nitrat (Kwon et al., 2019), sehingga oksigen terlarut pada setiap perlakuan cenderung mengalami penurunan pada hingga akhir pengamatan (Tabel 1). Hal tersebut ditunjukkan pada peningkatan kelimpahan total bakteri hingga akhir pengamatan yang dipengaruhi oleh kandungan oksigen terlarut (DO). Kandungan DO yang tinggi membantu kinerja bakteri dalam proses nitrifikasi dan denitrifikasi yang mungkin tidak dapat dicapai pada keadaan DO yang rendah yaitu <3 mg/l (Cui et al., 2019). 


\section{Laju Nitrifikasi (Nitrification Rate)}

Laju nitrifikasi disebut juga sebagai laju oksidasi amonia atau amonium secara biologis menjadi nitrit diikuti dengan oksidasi nitrit menjadi nitrat (Hong et al., 2018). Berdasarkan penelitian yang dilakukan, besarnya laju nitrifikasi menunjukkan besarnya perubahan (peningkatan) kadar nitrat pada waktu awal pengamatan hingga waktu akhir pengamatan pada setiap perlakuan. Hasil penelitian menunjukkan bahwa laju nitrifikasi pada 4 perlakuan yang dilakukan memiliki pola yang berbeda-beda (Gambar 6). Kombinasi antara bakteri dan Chlorella sp. (perlakuan C) memperlihatkan laju nitrifikasi paling tinggi yaitu $0.2 \mathrm{mg} \mathrm{NH}_{4}-\mathrm{N} \mathrm{l}^{-}$ ${ }^{1}$.jam ${ }^{-1}$, sedangkan laju nitrifikasi paling rendah terjadi pada penambahan probiotik bakteri (perlakuan A) yaitu $0.008 \mathrm{mg} \mathrm{NH}_{4}-\mathrm{N}^{-1}$.jam${ }^{-1}$. Kedua perlakuan lainnya yaitu perlakuan B (penambahan Chlorella sp.) dan D (kontrol) masing-masing memiliki laju nitrifikasi 0.169 dan $0.009 \mathrm{mg} \mathrm{NH}_{4}-\mathrm{N} \mathrm{l}^{-1}$.jam ${ }^{-1}$ (Gambar 6).

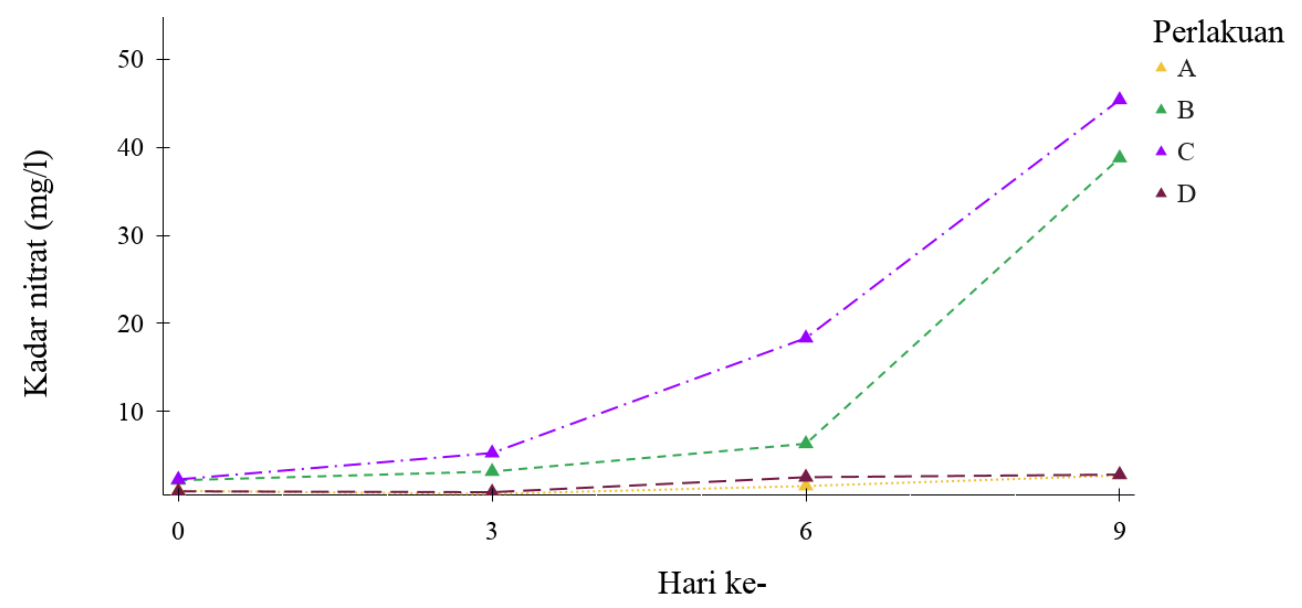

Gambar 6 Laju nitrifikasi pada perlakuan A (probiotik), B (Chlorella sp.), C (kombinasi Chlorella sp. dan probiotik), D (kontrol tanpa perlakuan)

Perlakuan yang memiliki laju nitrifikasi tertinggi adalah perlakuan $\mathrm{C}$ yaitu kombinasi antara bakteri dan Chlorella sp. sebesar $0.2 \mathrm{mg} \mathrm{NH}_{4}-\mathrm{N} \mathrm{l}^{-1}$.jam ${ }^{-1}$ atau 0.2 miligram amonium per liter per jam. Hal ini didasarkan pada kadar nitrat yang meningkat sebesar $1874 \%$ hingga akhir pengamatan (Gambar 5). Nitrat merupakan indikator penentu laju nitrifikasi, dimana semakin banyak terjadi nitrifikasi maka kadar nitrat akan semakin tinggi. Laju nitrifikasi tertinggi yang terjadi pada perlakuan C (kombinasi probiotik dan Chlorella sp.), dapat disebabkan oleh adanya Chlorella sp. Mikroalga Chlorella sp. memiliki pengaruh yang besar terhadap peningkatan nitrat. Hal tersebut dikarenakan adanya proses nitrifikasi dan penyerapan terhadap nitrat terjadi sangat sedikit karena mikroalga lebih menyukai bentuk senyawa amonium $\left(\mathrm{NH}_{4}{ }^{+}\right)$, sehingga penyerapannya lebih tinggi daripada nitrat (Minhas et al., 2016).

Tabel 2 Hasil analisis sidik ragam dan uji Duncan Multiple Range Test (DMRT)

\begin{tabular}{lccc}
\hline Faktor (Variabel) & Keterangan & Notasi & Signifikansi \\
\hline \multirow{3}{*}{ Perlakuan (P) } & A (probiotik) & $\mathrm{a}$ & \\
& D (kontrol) & $\mathrm{a}$ & $0.000435(\mathrm{p}<0.05)$ \\
B (Chlorella sp.) & $\mathrm{b}$ & \\
\hline C (kombinasi A dan B) & $\mathrm{b}$ & \\
Waktu (W) & Hari ke-0 & $\mathrm{a}$ & \\
& Hari ke-3 & $\mathrm{a}$ & $0.000905(\mathrm{p}<0.05)$ \\
& Hari ke-6 & $\mathrm{b}$ & \\
& Hari ke-9 & $\mathrm{c}$ & \\
\hline
\end{tabular}


Analisis sidik ragam (ANOVA) menggunakan data kadar nitrat yang ditransformasi menjadi logaritma natural (ln) menunjukkan bahwa terdapat perbedaan nyata antar perlakuan dan waktu (durasi perlakuan) terhadap perubahan (peningkatan) kadar nitrat ( $p$-value<0.05) (Tabel 2). Hasil uji lanjut Duncan Multiple Range Test (DMRT), menunjukkan angka rata-rata tertinggi terdapat pada perlakuan C (kombinasi probiotik dan mikroalga Chlorella sp.), diikuti dengan perlakuan B (mikroalga Chlorella sp.), perlakuan D (kontrol) dan terendah adalah perlakuan A (probiotik) (Tabel 2). Pada variabel waktu (W) rata-rata tertinggi terdapat pada hari ke-9, diikuti dengan hari ke-6, hari ke-3 dan terendah adalah hari ke-0 (Tabel 2). Hal tersebut menunjukkan bahwa perlakuan $\mathrm{C}$ (kombinasi) dan waktu ke-9 adalah perlakuan dan waktu yang memiliki perubahan (peningkatan) kadar nitrat paling tinggi karena memiliki rata-rata tertinggi. Hasil tersebut dipengaruhi oleh peningkatan kadar nitrat pada setiap perlakuan hingga akhir pengamatan. Kadar nitrat yang sangat tinggi menandakan bahwa kadar amonium yang terkandung dalam air cukup tinggi, dimana sebagian besar amonium mengalami proses nitrifikasi karena ada donor oksigen yang berasal dari aerasi (Riffiani, 2009) dan dari mikroalga sebagai penghasil oksigen bagi bakteri nitrifikasi (Jia dan Yuan, 2016).

Proses nitrifikasi yang terjadi menyebabkan senyawa amonium dan nitrit secara signifikan berubah menjadi nitrat, sehingga menyebabkan terjadinya akumulasi nitrat yang tinggi (Riffiani, 2009). Sementara itu, akumulasi nitrat berbanding terbalik dengan penyerapan kadar nitrat oleh mikroalga dan bakteri yang terjadi. Hal tersebut terjadi karena mikroalga lebih menyukai senyawa berbentuk amonium $\left(\mathrm{NH}_{4}{ }^{+}\right)$karena lebih sedikit energi yang dikeluarkan dalam penyerapannya daripada penyerapan senyawa nitrat (Minhas et al., 2016). Mikroalga lebih mengutamakan penyerapan senyawa amonium dibandingkan dengan penyerapan senyawa bentuk nitrat, karena penyerapan amonium dapat melalui membran sel secara langsung, sedangkan untuk nitrat harus dilakukan proses translokasi ion terlebih dahulu karena membran tidak bersifat permeabel untuk nitrat (Riffiani, 2009). Mikroalga memiliki pengaruh yang sangat besar terhadap peningkatan senyawa nitrat, terlihat dari perlakuan yang memiliki rerata paling tinggi yaitu perlakuan kombinasi probiotik dan mikroalga (C) dan pelakuan Chlorella sp. (B), yang keduanya merupakan perlakuan dengan adanya penambahan mikroalga Chlorella sp., berbeda dengan perlakuan A (probiotik) dan perlakuan D (kontrol) yang tanpa adanya penambahan Chlorella sp.

Hubungan mikroalga Chlorella sp. dengan bakteri nitrifikasi-denitrifikasi dapat dikatakan sangatlah kompleks. Konsorsium mikroalga dengan bakteri dapat membentuk hubungan yang berlangsung secara sinergis. Mikroalga Chlorella sp. dapat menghasilkan berbagai zat organik yang dapat diasimilasi oleh bakteri secara langsung serta menghasilkan oksigen untuk kebutuhan bakteri dalam proses nitrifikasi (Jia dan Yuan, 2016). Di dalam proses fotosintesis untuk menghasilkan oksigen, mikroalga Chlorella sp. menyerap $\mathrm{CO}_{2}$ sehingga meningkatkan penyerapan amonium dan konsentrasi ion $\mathrm{OH}^{-}$serta banyak melepaskan ion $\mathrm{H}^{+}$(KnudHansen, 1998 dalam Jia dan Yuan, 2016), dimana melimpahnya ion hidrogen yang terlepas dapat menurunkan pH (Le et al., 2018). Hubungan bakteri dan mikroalga Chlorella sp. memiliki kesamaan, hal itu karena pelepasan ion hidrogen sama halnya pada proses fotosintesis (mikroalga) juga terjadi pada proses nitrifikasi (bakteri), yaitu saat terjadinya oksidasi amonia (amonium) menjadi nitrit (Le et al., 2018).

\section{KESIMPULAN}

Laju nitrifikasi pada setiap perlakuan memiliki pola yang berbeda-beda tetapi relatif meningkat hingga akhir pengamatan. Laju nitrifikasi tertinggi terjadi pada perlakuan $\mathrm{C}$ (kombinasi probiotik dan Chlorella sp.) yaitu $0.2 \mathrm{mg} \mathrm{NH}_{4}-\mathrm{N} \mathrm{l}^{-1}$.jam ${ }^{-1}$, diikuti perlakuan B (Chlorella sp.), D (kontrol), dan A (probiotik) masing-masing sebesar 0.169, 0.009 dan $0.008 \mathrm{mg} \mathrm{NH}_{4}-\mathrm{N} \mathrm{l}^{-1}$.jam ${ }^{-1}$. Persentase perubahan (peningkatan) kadar nitrat dari awal hingga akhir pengamatan dari yang tertinggi secara berurutan yaitu perlakuan C sebesar $1874 \%$, perlakuan B sebesar $1664 \%$, D sebesar 200\% dan perlakuan A sebesar 175\%. Hasil analisis sidik ragam dan uji DMRT menunjukkan bahwa terdapat perbedaan antar perlakuan dan waktu terhadap perubahan kadar nitrat ( $p$-value $<0.05$ ) dengan rata-rata perubahan (peningkatan) kadar nitrat tertinggi terdapat pada perlakuan $\mathrm{C}$ dan hari ke9. 


\section{DAFTAR PUSTAKA}

[APHA] American Public Health Association. 1989. Standar Methods for The Examination of Water and Wastewater. Washington DC (US): American Public Control Federation.

[EPA] Environmental Protection Agency. 1974. Methods for Chemical Analysis of Water and Wastes. Washington DC (US): EPA.

[LIPI] Lembaga Ilmu Pengetahuan Indonesia. 2015. Eutrofikasi Penyebab Kematian Massal Ikan [Internet]. [diunduh 2020 Jan 12]. Tersedia pada: http://lipi.go.id/.

Adyasari D, Oehler T, Afiati N, Moosdorf N. 2018. Groundwater nutrient inputs into an urbanized tropical estuary system in Indonesia. Science of the Total Environment. 627(1): 1066-1079.

Agustiyani D, Imamuddin H, Gunawan E, Darusman LK. 2007. Proses nitrifikasi oleh kultur mikroba penitrifikasi N-Sw dan zeolit. Jurnal Ilmiah Nasional. 8(5): 405-411.

Al-Mamoori SOH, Al-Yaseen BM, Jabuk SIA, Kamil ZS, Jawad ZF, Naji OM. 2020. Bioremediation by using the microalgae Chlorella vulgaris to remove phosphate and nitrite from the domestic waste water treatment plant in Iraq. The Journal of Research on the Lepidoptera. 51(1): 660-668.

Arifin F. 2012. Uji kemampuan Chlorella sp. sebagai bioremidiator limbah cair tahu [tesis]. Malang (ID): UIN Maliki Malang.

Arifin M. 2000. Pengolahan limbah hotel berbintang [tesis]. Bogor (ID): Institut Pertanian Bogor.

Boroh R, Litaay M, Umar MR, Ambeng. 2019. Pertumbuhan Chlorella sp. pada beberapa kombinasi media kultur. BIOMA: Jurnal Biologi Makassar. 4(2): 129-137.

Carritt DE, Kanwisher JW. 1959. Electrode system for measuring dissolved oxygen. Anal Chem 31: 5-9.

Chen H, Wang Q. 2020. Microalgae-based nitrogen bioremediation. Algal Research. 46: 10-17.

Chen Z, Jiang Y, Chang Z, Wang J, Song X, Huang Z, Chen S, Li J. 2020. Denitrification characteristics and pathways of a facultative anaerobic denitrifying strain, Pseudomonas denitrificans G1. Journal of Bioscience and Bioengineering. 30: 1-8.

Chilmawati D, Suminto. 2008. Penggunaan media kultur yang berbeda terhadap pertumbuhan Chlorella sp. Jurnal Saintek Perikanan. 4(1): 42-49.

Cui B, Yang Q, Liu X, Huang S, Yang Y, Liu Z. 2019. The effect of dissolved oxygen concentration on longterm stability of partial nitrification process. Journal of Environmental Sciences. 30: 1-9.

Cytryn E, Levkovitch I, Negreanu Y, Dowd S, Frenk S, Silber A. 2012. Impact of short-term acidification on nitrification and nitrifying bacterial community dynamics in soilless cultivation media. Appl Environ Microbiol. 78(18): 6576-6582.

Djazari M, Rahmawati D, Nugroho MA. 2013. Pengaruh sikap menghindari risiko sharing dan knowledge selfefficacy terhadap informal knowledge sharing pada mahasiswa FISE UNY. Jurnal Nominal. 2(2): 181209.

Djoharam V, Riani E, Yani M. 2018. Analisis kualitas air dan daya tampung beban pencemaran Sungai Pesanggrahan di wilayah Provinsi DKI Jakarta. Jurnal Pengelolaan Sumberdaya Alam dan Lingkungan 8(1): 127-133.

Djokosetiyanto D, Sunarma A, Widanarni. 2006. Perubahan ammonia $\left(\mathrm{NH}_{3}-\mathrm{N}\right)$, nitrit $\left(\mathrm{NO}_{2}-\mathrm{N}\right)$ dan nitrat $\left(\mathrm{NO}_{3}-\mathrm{N}\right)$ pada media pemeliharaan ikan nila merah (Oreochromis sp.) di dalam sistem resirkulasi. Jurnal Akuakultur Indonesia. 5: 13-20.

Feng P, Xu Z, Qin L, Alam AM, Wang Z, Zhu S. 2020. Effects of different nitrogen sources and light paths of flat plate photobioreactors on the growth and lipid accumulation of Chlorella sp. GN1 outdoors. Bioresource Technology. 301: 1-9.

Gilhawley F. 2008. Factors governing nitrification in an activated sludge system treating a pharmaceutical wastewater [tesis]. Dublin (IE): Dublin City University.

Grunditz C, Dalhammar G. 2001. Development of nitrification inhibition assays using pure cultures of Nitrosomonas and Nitrobacter. Water Research. 35(2): 433-440. 
Herlambang A, Marsidi R. 2003. Proses denitrifikasi dengan sistem biofilter untuk pengolahan air limbah yang mengandung nitrat. J Tek Ling. 4(1): 46-55.

Hong Y, Wang Y, Wu J, Jiao L, He X, Wen X, Chang X. 2018. Developing a mathematical modeling method for determining the potential rates of microbial ammonia oxidation and nitrite oxidation in environmental samples. International Biodeterioration \& Biodegradation. 133: 116-123.

Ikhsan MK, Rudiyanti S, Ain C. 2020. Hubungan antara nitrat dan fosfat dengan kelimpahan fitoplankton di Waduk Jatibarang Semarang. MAQUARES. 9(1): 23-30.

Jia H, Yuan Q. 2016. Removal of nitrogen from wastewater using microalgae and microalgae-bacteria consortia. Cogent Environmental Science. 2(1): 1-15.

Karangan J, Sugeng, B, Sulardi. 2019. Uji keasaman air dengan alat sensor pH di STT Migas Balikpapan. Jurnal Keilmuan Teknik Sipil. 2(1): 65-72.

Kwon G, Kim H, Song C, Jahng D. 2019. Co-culture of microalgae and enriched nitrifying bacteria for energyefficient nitrification. Biochemical Engineering Journal.152: 1-54.

Le TTH, Fettig J, Meon G. 2018. Kinetics and simulation of nitrification at various $\mathrm{pH}$ values of a polluted river in the tropics. Ecohydrology \& Hydrobiology. 118: 1-12.

Lihawa F, Mahmud M. 2017. Evaluasi karakteristik kualitas air Danau Limboto. Jurnal Pengelolaan Sumberdaya Alam dan Lingkungan. 7(3): 260-266.

Lomas MW, Lipschultz F. 2006. Forming the primary nitrite maximum: nitrifiers or phytoplankton?. Limnol Oceanogr. 51(5): 2453-2467.

Ma X, Zhou W, Fu Z, Cheng Y, Min M, Liu Y, Ruan R. 2014. Effect of wastewater-borne bacteria on algal growth and nutrients removal in wastewater-based algae cultivation system. Bioresource Technology. 167: 8-13.

Martinez S, Alvarez S, Marin MR, Delgado DMM. 2019. Food consumption contribution to nitrogen pollution of cities in Northern and Southern Europe. Sustainable Cities and Society. 50: 1-10.

Mattjik AA, Sumertajaya M. 2000. Perancangan Percobaan dengan Aplikasi SAS dan Minitab. Bogor (ID): IPB Press.

Minhas AK, Hodgson P, Barrow CJ, Adholeya A. 2016. A review on the assessment of stress conditions for simultaneous production of microalgal lipids and carotenoids. Front Microbiol. 7: 1-19.

Nurhayati C, Hamzah B, Pambayun R. 2014. Pengaruh pH, konsentrasi isolat Chlorella vulgaris dan waktu pengamatan terhadap tingkat cemaran limbah cair crumb rubber. Jurnal Dinamika Penelitian Industri. 25(2): 97-106.

Paul I, Panigrahi AK, Datta S. 2020. Influence of nitrogen cycle bacteria on nitrogen mineralisation, water quality and productivity of freshwater fish pond: A review. Asian Fisheries Science. 33: 145-160.

Persulessy ER, Lembang FK, Djidin H. 2016. Penilaian cara mengajar menggunakan rancangan acak lengkap (studi kasus: Jurusan Matematika FMIPA UNPATTI). Jurnal Ilmu Matematika dan Terapan. 10(1): 916.

Prabowo R. 2017. Kadar nitrit pada sumber air sumur di Kelurahan Meteseh, Kec. Tembalang, Kota Semarang. Jurnal Ilmiah Cendekia Eksakta. 1(1): 55-61.

Prayitno J. 2015. Pola pertumbuhan dan pemanenan biomassa dalam fotobioreaktor mikroalga untuk penangkapan karbon. Jurnal Teknologi Lingkungan. 17(1): 45-52.

Riffiani R. 2009. Peningkatan kualitas akuakultur menggunakan teknologi biofilter mikroalga imobil. Biosfera 26(3): 124-130.

Rusdiani RR, Boedisantoso R, Hanif M. 2016. Optimalisasi teknologi fotobioreaktor mikroalga sebagai dasar perencanaan strategi mitigasi gas $\mathrm{CO}_{2}$. Jurnal Teknik ITS. 5(2): 2337-3539.

Rustadi. 2009. Eutrofikasi nitrogen dan fosfor serta pengendaliannya dengan perikanan di Waduk Sermo. Jurnal Manusia dan Lingkungan. 16(3): 176-186. 
Suprianto, Redjeki ES, Dadiono MS. 2019. Optimalisasi dosis probiotik terhadap laju pertumbuhan dan kelangsungan hidup ikan nila (Oreochromis niloticus) pada sistem bioflok. Journal of Aquaculture and Fish Health. 8(2): 80-86.

Suswanti I, Sutamihardja RTM, Arrisujaya D. 2019. Potensi senyawaan nitrogen dan fosfat pada pencemaran Sungai Ciliwung hulu Kota Bogor. Jurnal Sains Natural Universitas Nusa Bangsa. 9(1): 11-21.

Taziki M, Hossein A, Marcia AM. 2015. Growth of Chlorella vulgaris in high concentrations of nitrate and nitrite for wastewater treatment. Current Biotechnology. 4(3): 1-7.

Zulfia N, Aisyah. 2013. Status trofik Perairan Rawa Pening ditinjau dari kandungan unsur hara $\left(\mathrm{NO}_{3}\right.$ dan $\left.\mathrm{PO}_{4}\right)$ serta klorofil-a. BAWAL 5(3): 189-199. 